\title{
The effect of the relationship between post-cardiotomy neutrophil/lymphocyte ratio and platelet counts on early major adverse events after isolated coronary artery bypass grafting
}

\author{
izole koroner arter baypas greftleme sonrası postkardiyotomi nötrofil/lenfosit oranı ve \\ trombosit sayısı arasındaki ilişkinin erken dönem majör advers olaylar üzerine etkisi
}

\author{
Mustafa Abanoz' ${ }^{1}$, Mesut Engin² ${ }^{2}$ \\ Institution where the research was done: \\ University of Health Sciences, Şanlıurfa Mehmet Akif Inan Training and Research Hospital, Şanlıurfa, Turkey
}

Author Affiliations:

'Department of Cardiovascular Surgery, University of Health Sciences, Şanlıurfa Mehmet Akif Inan Training and Research Hospital, Şanlıurfa, Turkey 2Department of Cardiovascular Surgery, University of Health Sciences, Bursa Yüksek Ihtisas Training and Research Hospital, Bursa, Turkey

\begin{abstract}
Background: In this study, we aimed to investigate the role of postcardiotomy neutrophil, lymphocyte, and platelet counts in predicting major adverse events after coronary artery bypass grafting.

Methods: A total of 373 patients (257 males, 116 females; median age 63 , range 33 to 85 years) who underwent isolated coronary artery bypass grafting under cardiopulmonary bypass between January 2015 and January 2020 were retrospectively analyzed. The patients who did not develop any postoperative major adverse event were included in Group 1, while those who did constituted Group 2. Preoperative neutrophil-to-lymphocyte ratio, postcardiotomy neutrophil-to-lymphocyte ratio, postoperative Day 1 neutrophil-to-lymphocyte ratio, and neutrophil-to-lymphocyte x platelet ratio were calculated.
\end{abstract}

Results: Preoperative neutrophil counts, C-reactive protein values, neutrophilto-lymphocyte ratio, total perfusion time, and length of intensive care unit and hospital stay were significantly higher in Group $2(p=0.019, p=0.028$, $\mathrm{p}<0.001, \mathrm{p}=0.027, \mathrm{p}<0.001$, and $\mathrm{p}<0.001$, respectively). Post-cardiotomy neutrophil, neutrophil-to-lymphocyte ratio, and neutrophil-to-lymphocyte $\mathrm{x}$ platelet ratio, along with the postoperative first day white blood cell count, neutrophil, C-reactive protein, neutrophil-to-lymphocyte ratio, and neutrophil-to-lymphocyte $\mathrm{x}$ platelet ratio were significantly higher in Group $2(\mathrm{p}=0.004, \mathrm{p}<0.001, \mathrm{p}<0.001, \mathrm{p}=0.019, \mathrm{p}=0.003, \mathrm{p}=0.001, \mathrm{p}<0.001$, and $\mathrm{p}=0.041$, respectively). The post-cardiotomy platelet and lymphocyte counts and postoperative first day lymphocyte counts were significantly lower in Group 2 ( $\mathrm{p}<0.001, \mathrm{p}=0.007$, and $\mathrm{p}=0.009$, respectively).

Conclusion: Post-cardiotomy neutrophil-to-lymphocyte ratio and neutrophilto-lymphocyte $\mathrm{x}$ platelet ratio can be easily accessible, inexpensive complete blood count parameters and may be more valuable in predicting major adverse events in patients undergoing coronary artery bypass grafting.

Keywords: Coronary artery bypass grafting, extracorporeal circulation, inflammation, leukocytes, neutrophil/lymphocyte ratio, platelet count.
$\ddot{O} Z$

Amaç: Bu çalışmada, koroner arter baypas greftleme sonrasında majör advers olayları öngörmede postkardiyotomi nötrofil, lenfosit ve trombosit sayısının rolü araştırıldı.

Calısma planı: Ocak 2015 - Ocak 2020 tarihleri arasında kardiyopulmoner baypas ile izole koroner arter baypas greftleme yapılan toplam 373 hasta (257 erkek, 116 kadın; ort. yaș: 63 yıl; da ğılım, 33-85 yıl) retrospektif olarak incelendi. Ameliyat sonrası majör advers olay gelişmeyen hastalar Grup 1'e alınırken, gelişen hastalar Grup 2'ye dahil edildi. Ameliyat öncesi nötrofil/lenfosit oran1, postkardiyotomi nötrofil/lenfosit oran1, ameliyat sonrası birinci gün nötrofil/lenfosit oranı ve nötrofil/lenfosit $\mathrm{x}$ trombosit oranı hesaplandı.

Bulgular: Grup 2'de ameliyat öncesi nötrofil sayıları, C reaktif protein değerleri, nötrofil/lenfosit oranı, toplam perfüzyon süresi ve yoğun bakım ünitesinde ve hastanede kalış süresi anlamlı olarak daha yüksekti (sirasiyla, $\mathrm{p}=0.019, \mathrm{p}=0.028, \mathrm{p}<0.001, \mathrm{p}=0.027, \mathrm{p}<0.001$ ve $\mathrm{p}<0.001$ ). Postkardiyotomi nötrofil, nötrofil/lenfosit oranı ve nötrofil/lenfosit $\mathrm{x}$ trombosit oranı ile ameliyat sonrası birinci gün beyaz kan hücre sayısı, nötrofil, C-reaktif protein, nötrofil/lenfosit oranı ve nötrofil/lenfosit $\mathrm{x}$ trombosit oranı Grup 2'de anlamlı olarak yüksek idi (sırasıyla, $\mathrm{p}=0.004$, $\mathrm{p}<0.001, \mathrm{p}<0.001, \mathrm{p}=0.019, \mathrm{p}=0.003, \mathrm{p}=0.001, \mathrm{p}<0.001$ ve $\mathrm{p}=0.041)$. Grup 2'de postkardiyotomi trombosit ve lenfosit sayısı ve ameliyat sonras1 ilk gün lenfosit sayıları ise anlamlı olarak daha düşüktü (sırasıyla, $\mathrm{p}<0.001$, $\mathrm{p}=0.007$ ve $\mathrm{p}=0.009$ ).

Sonuç: Postkardiyotomi nötrofil/lenfosit oranı ve nötrofil/ lenfosit $\mathrm{x}$ trombosit oranı kolaylıkla ulaşılabilir ve ucuz hemogram parametrelerinden olup, koroner arter baypas greftleme yapılan hastalarda majör advers olayları öngörmede daha değerli olabilir.

Anahtar sözcükler: Koroner arter baypas greftleme, ekstrakorporeal dolaşım, enflamasyon, lökositler, nötrofil//lenfosit oranı, trombosit sayısı.

Received: October 08, 2020 Accepted: November 23, 2020 Published online: January 13, 2021

Correspondence: Mesut Engin, MD. SBÜ Bursa Yüksek intisas Eğitim ve Araştırma Hastanesi Kalp ve Damar Cerrahisi Kliniği, 16310 Yıldırım, Bursa, Türkiye. Tel: +90 507 - 2066622 e-mail: mesut_kvc_cor@hotmail.com

Abanoz M, Engin M. The effect of the relationship between post-cardiotomy neutrophil/lymphocyte ratio and platelet counts on early major adverse events after isolated coronary artery bypass grafting. Turk Gogus Kalp Dama 2021;29(1):36-44 
Coronary artery bypass grafting (CABG) surgery is one of the most valuable treatment methods for coronary artery disease. In recent years, with the developments in cardiopulmonary bypass (CPB) technology, these operations can be performed with very low mortality and morbidity rates. However, following these operations, major adverse events (MAEs) such as postoperative rhythm problems, renal failure, cerebrovascular events, and mortality may occur. ${ }^{[1]}$ It is particularly important to anticipate these potential problems and take necessary measures.

Inflammation plays a key role in the pathogenesis and progression of cardiovascular diseases. Therefore, many inflammatory parameters have been the subject of research in terms of showing the progression of CABG operations. One of the most important of these parameters and the subject of many studies is the neutrophil-to-lymphocyte ratio (NLR). Systemic inflammatory response is stimulated during heart surgery with a pump. As a result of this response, the NLR is positively affected, which may induce undesired results in the postoperative period. ${ }^{[2,3]}$ Platelets are important mediators of inflammatory and ischemic damage in vital organs. It has been shown that low platelet count after CABG is associated with early mortality and poor prognosis. ${ }^{[4-6]}$ In addition, the elevation of NLR and decreased platelet count within the first $12 \mathrm{~h}$ after major abdominal surgery have been shown to be the predictors for poor postoperative results. ${ }^{[7]}$

In this study, we aimed to investigate the role of post-cardiotomy NLR and platelet counts in predicting MAEs after CABG under CPB.

\section{PATIENTS AND METHODS}

This single-center, retrospective study was conducted at University of Health Sciences, Şanlıurfa Mehmet Akif Inan Training and Research Hospital between January 2015 and January 2020. Patients who underwent isolated CABG under CPB were screened. Demographic data, preoperative blood parameters, and operative data were obtained from the hospital registry. Postoperative variables were accessed from the patients' intensive care unit (ICU) daily observation cards and patient files. Reoperations, emergency operations, patients who had acute coronary syndromes within the past month, combined surgeries, those with systemic inflammatory diseases, those under steroid therapy, those with chronic autoimmune diseases, those with preoperative creatinine values of $\geq 1.5 \mathrm{mg} / \mathrm{dL}$, left ventricular ejection fraction $\leq 30 \%$, patients who received intraoperative intra-aortic balloon support, and those with chronic liver and hematological diseases were excluded from the study. Finally, a total of 373 patients (257 males, 116 females; median age 63, range 33 to 85 years) who met the inclusion criteria were included in the study. The European System for Cardiac Operative Risk Evaluation II (EuroSCORE II) values were calculated preoperatively for all patients. The primary outcome measure of the study was the development of an in-hospital major adverse event (MAE). The patients who did not develop postoperative MAEs were included in Group $1(\mathrm{n}=315)$ and those who did constituted Group $2(n=58)$. A written informed consent was obtained from each patient. The study protocol was approved by the Harran University Faculty of Medicine Ethics Committee. The study was conducted in accordance with the principles of the Declaration of Helsinki.

\section{Preoperative variables}

Hypertension was defined as the use of at least one antihypertensive drug and/or arterial blood pressure above $140 / 90 \mathrm{mmHg}$; hyperlipidemia as the use of antilipidemic therapy and/or blood low density lipoprotein levels above $150 \mathrm{mg} / \mathrm{dL}$; diabetes mellitus as the antidiabetic medication use, fasting blood glucose level above $126 \mathrm{mg} / \mathrm{dL}$ or above $200 \mathrm{mg} / \mathrm{dL}$ during routine examinations; preoperative renal failure as creatinine values above $1.5 \mathrm{mg} / \mathrm{dL}$ or receiving renal replacement therapy; preoperative carotid artery disease as a preoperative Doppler ultrasonographic evidence with at least one-sided lesion causing stenosis of at least 50\%; preoperative chronic obstructive pulmonary disease as a post-bronchodilator forced expiratory volume in $1 \mathrm{sec} /$ forced vital capacity of $<70 \%$; and preoperative cerebrovascular accident as having a history of neurological deficit for at least $24 \mathrm{~h}$.

\section{Definition of MAEs}

In-hospital mortality was defined as the mortality occurring in the hospital during the postoperative period; postoperative myocardial infarction as having increased biomarker values (creatine kinase-MB or cardiac troponin levels) by at least five-fold, $\mathrm{Q}$ waves occurring in at least two electrocardiography leads, or development of ST segment changes or new left bundle branch block; renal failure as postoperative creatinine levels increasing to at least twice the preoperative value or need for renal replacement therapy; cerebrovascular accident as central neurological deficit for at least $24 \mathrm{~h}$ after the operation; infection as mediastinal infection involving bone and muscle structures requiring reoperation, pneumonia or septicemia requiring antibiotherapy; serious postoperative rhythm problems 
as atrial fibrillation and ventricular tachycardia/ fibrillation requiring aggressive medical treatment and/or cardioversion, leading to hemodynamic instability and general condition impairment during the postoperative period; bleeding as postoperative drainage disrupting the hemodynamic stability and requiring reoperation; and prolonged ventilation as the need for ventilation for more than $24 \mathrm{~h}$ after the operation. The patients who fulfilled at least one of these definitions were included in Group 2.

\section{Laboratory tests}

Hematological parameters were examined using an automatic analyzer. Preoperative NLR (pre-NLR), post-cardiotomy NLR (PC-NLR, complete blood count assessment performed within the first hour of postoperative transfer into the ICU), and postoperative Day 1 NLR (po1-NLR) were calculated. The neutrophilto-lymphocyte $\mathrm{x}$ platelet ratio (NLPR) calculation was performed using the following formula: ${ }^{[8]}$

$\mathrm{NLPR}=\frac{\text { Neutrophil } \operatorname{count}\left(10^{3} / \mu \mathrm{L}\right) \times 100}{\text { Lymphocyte } \operatorname{count}\left(10^{3} / \mu \mathrm{L}\right) \times \text { Platelet } \operatorname{count}\left(10^{3} / \mu \mathrm{L}\right.}$

\section{Statistical analysis}

Statistical analysis was performed using the IBM SPSS version 21.0 (IBM Corp., Armonk, NY, USA). Descriptive data were expressed in mean \pm standard deviation (SD), median (min-max) or number and frequency. The Kolmogorov-Smirnov and Shapiro-Wilk tests were used to check normality distribution. The Student's t-test was performed to analyze normally distributed data, while the Mann-Whitney $U$ test was used to analyze non-normally distributed data. The categorical variables were compared using the chi-square test. A multivariate logistic regression analysis was carried out to analyze the predictors of poor postoperative results, for which two models were created. The PC-NLR and platelet counts were evaluated separately in Model 1, while they were evaluated as post-cardiotomy NLPR (PC-NLPR) in Model 2. The receiver operating characteristic (ROC) curve analysis was performed to identify the predictive value of preNLR and PC-NLPR for poor postoperative results and the areas under the curve (AUC) were calculated. A $p$ value of $<0.05$ was considered statistically significant.

\section{RESULTS}

Baseline demographic and clinical features of the patients are presented in Table 1. Group 1 consisted of 315 patients with a median age of 61 (range, 33 to 81) years, while Group 2 had 58 patients with a median age of 66 (range, 39 to 85$)$ years $(\mathrm{p}=0.018)$. The groups were similar in terms of sex, hypertension, smoking, body mass index, hyperlipidemia, ejection fraction, and current medical treatments (such as statin use and betablocker therapy). Diabetes mellitus, previous coronary intervention rates, and EuroSCORE II values were significantly higher in Group $2(\mathrm{p}=0.015, \mathrm{p}=0.032$, and $\mathrm{p}<0.001$, respectively).

The preoperative laboratory parameters and operative data of the patients are presented in Table 2. There were no significant differences between the groups in terms of white blood cell (WBC), hematocrit (Hct), platelet counts, urea, creatinine, NLPR, and cross-clamp times. However, the neutrophil counts, C-reactive protein (CRP) values, NLR, total perfusion time, and length of ICU and hospital stay were significantly higher in Group $2(\mathrm{p}=0.019, \mathrm{p}=0.028, \mathrm{p}<0.001, \mathrm{p}=0.027, \mathrm{p}<0.001$, and $\mathrm{p}<0.001$, respectively).

Postoperative blood parameters of the patients are presented in Table 3. Two groups were similar in terms of $\mathrm{WBC}$ and Hct values in the post-cardiotomy period. The post-cardiotomy neutrophil, PC-NLR, and PC-NLPR values, along with the postoperative first day WBC, neutrophil, CRP, PO1-NLR, and PO1-NLPR values were significantly higher $(\mathrm{p}=0.004, \mathrm{p}<0.001$, $\mathrm{p}<0.001, \mathrm{p}=0.019, \mathrm{p}=0.003, \mathrm{p}=0.001, \mathrm{p}<0.001$, and $\mathrm{p}=0.041$, respectively) while post-cardiotomy platelet and lymphocyte counts and postoperative first day lymphocyte counts were significantly lower in Group 2 ( $\mathrm{p}<0.001, \mathrm{p}=0.007$, and $\mathrm{p}=0.009$, respectively).

Following $\mathrm{CABG}$ operations under $\mathrm{CPB}$, logistic regression analysis was performed to evaluate the predictors of MAEs (Table 4). According to the multivariate analysis, the independent predictors of postoperative MAEs included being above the age of 65 years (odds ratio [OR]: $0.670,95 \%$ confidence interval $[\mathrm{CI}]$ : 0.576-0.894 $\mathrm{p}=0.045$ ), EuroSCORE II (OR: 1.497, 95\% CI: 1.090-2.165, p=0.005) preoperative CRP (OR: 1.061, 95\% CI: 1.015-1.110, $\mathrm{p}=0.009$ ), postoperative first day CRP (OR: $1.01095 \%$ CI: $1.001-1.020, \mathrm{p}=0.030$ ), pre-NLR (OR: $1.130,95 \%$ CI: $1.050-1.216, \mathrm{p}=0.001)$, PC-NLR (OR: $1.520,95 \%$ CI: $1.202-1.921, \mathrm{p}<0.001)$, post-cardiotomy platelet counts (OR: 0.976, 95\% CI: 0.678-0.998, p=0.014), and PO1-NLR (OR: 1.127, 95\% CI: 1.010-1.257, $\mathrm{p}=0.033$ ) for Model 1, and EuroSCORE II (OR: $1.230,95 \%$ CI: 1.007-2.112, p=0.012), preoperative CRP (OR: 1.028, 95\% CI: $1.009-1.410, \mathrm{p}=0.006$ ), postoperative first day CRP (OR: 1.016, 95\% CI: 1.006-1.127, p=0.002), pre-NLR (OR: 1.247, 95\% CI: 1.076-2.125, p<0.012), and PC-NLPR (OR: 1.968, 95\% CI: 1.216-3.419, $\mathrm{p}<0.001)$ in Model 2. 
Table 1. Baseline demographic characteristics and operative data of patients

\begin{tabular}{|c|c|c|c|c|c|c|c|c|c|c|c|}
\hline \multirow[b]{2}{*}{ Variables } & \multicolumn{5}{|c|}{ Group $1(n=315)$} & \multicolumn{5}{|c|}{ Group $2(\mathrm{n}=58)$} & \multirow[b]{2}{*}{$p$} \\
\hline & $\mathrm{n}$ & $\%$ & Mean \pm SD & Median & $\mathrm{IQR}$ & $\mathrm{n}$ & $\%$ & Mean \pm SD & Median & IQR & \\
\hline Age (year) & & & & 61 & $33-81$ & & & & 66 & $39-85$ & $0.024 \ddagger$ \\
\hline \multicolumn{12}{|l|}{ Sex } \\
\hline Male & 216 & 68.5 & & & & 41 & 70.6 & & & & $0.748^{*}$ \\
\hline Hypertension & 210 & 66.6 & & & & 40 & 68.9 & & & & $0.517 *$ \\
\hline Diabetes mellitus & 63 & 20 & & & & 20 & 34.4 & & & & $0.015^{*}$ \\
\hline Previous PCI & 74 & 23.4 & & & & 22 & 37.9 & & & & $0.032 *$ \\
\hline Current smoker & 76 & 24.1 & & & & 15 & 25.8 & & & & $0.859 *$ \\
\hline COPD & 37 & 11.7 & & & & 13 & 22.4 & & & & $0.098 *$ \\
\hline Previous CVA & 26 & 8.2 & & & & 9 & 15.5 & & & & $0.216^{*}$ \\
\hline EuroSCORE II & & & & 19 & $0.5-5.2$ & & & & 2.7 & $0.5-9.4$ & $<0.001 \%$ \\
\hline BMI $\left(\mathrm{kg} / \mathrm{m}^{2}\right)$ & & & & 28.4 & $22.7-38.5$ & & & & 29 & $23-39$ & $0.240^{*}$ \\
\hline Hyperlipidemia & 90 & 28.5 & & & & 17 & 29.3 & & & & $0.896^{*}$ \\
\hline Ejection fraction & & & $50.5 \pm 7.8$ & & & & & $51 \pm 9.1$ & & & $0.142 \dagger$ \\
\hline ASA use & 101 & 32 & & & & 23 & 39.6 & & & & $0.251^{*}$ \\
\hline ACEI/ARB use & 115 & 36.5 & & & & 23 & 39.6 & & & & $0.648 *$ \\
\hline Statin use & 101 & 32 & & & & 19 & 32.7 & & & & $0.918 *$ \\
\hline Beta blocker use & 127 & 40.3 & & & & 25 & 43.1 & & & & $0.569 *$ \\
\hline
\end{tabular}

SD: Standard deviation; IQR: Interquartile range; PCI: Percutaneous coronary intervention; COPD: Chronic obstructive pulmonary disease; CVA: Cerebrovascular accident; EuroSCORE II: European System for Cardiac Operative Risk Evaluation II; BMI: Body mass index; ASA: Acetylsalicylic acid; ACEI: Angiotensin-converting enzyme inhibitor; ARB: Angiotensin receptor blocker; * Chi-square test; $\dagger$ Student’s t-test; $\ddagger$ Mann-Whitney U test.

Table 2. Preoperative laboratory data and perioperative data of patients

\begin{tabular}{|c|c|c|c|c|c|}
\hline \multirow[b]{2}{*}{ Variables } & \multicolumn{2}{|c|}{ Group $1(n=315)$} & \multicolumn{2}{|c|}{ Group $2(n=58)$} & \multirow[b]{2}{*}{$p \ddagger$} \\
\hline & Median & IQR & Median & IQR & \\
\hline White blood cell $\left(10^{3} / \mu \mathrm{L}\right)$ & 8.1 & $4.3-15$ & 8.3 & $4.9-14.9$ & 0.329 \\
\hline Hematocrit (\%) & 40.9 & $32.4-51.5$ & 41 & $33-49.5$ & 0.314 \\
\hline Platelet $\left(10^{3} / \mu \mathrm{L}\right)$ & 241.6 & $130-488.3$ & 254 & $136-456.2$ & 0.367 \\
\hline Neutrophil $\left(10^{3} / \mu \mathrm{L}\right)$ & 4.6 & $1.7-10.6$ & 4.9 & $2.8-11.2$ & 0.019 \\
\hline Lymphocyte $\left(10^{3} / \mu \mathrm{L}\right)$ & 2 & $0.7-4.1$ & 1.8 & $0.8-3.4$ & 0.003 \\
\hline Creatinine (mg/dL) & 1.1 & $0.5-1.49$ & 0.94 & $0.6-1.49$ & 0.317 \\
\hline Urea (mg/dL) & 12 & $10-22$ & 12 & $10-24$ & 0.263 \\
\hline C-reactive protein $(\mathrm{mg} / \mathrm{dL})$ & 8.3 & $0.2-57.4$ & 10.8 & $0.9-73$ & 0.028 \\
\hline NLR & 2.5 & $0.9-7.3$ & 3.2 & $1.2-9.9$ & $<0.001$ \\
\hline NLPR & 1 & $0.2-4.6$ & 1 & $0.3-4.7$ & 0.330 \\
\hline Total perfusion time (min) & 105 & $45-163$ & 110 & $50-165$ & 0.027 \\
\hline Cross-clamp time (min) & 75 & $28-90$ & 79 & $30-96$ & 0.646 \\
\hline Number of distal anastomoses & 3 & $1-5$ & 3 & $1-5$ & 0.829 \\
\hline Total ICU stay (days) & 2 & $2-4$ & 4 & $2-21$ & $<0.001$ \\
\hline Total hospital stay (days) & 7 & $6-10$ & 11 & $10-28$ & $<0.001$ \\
\hline
\end{tabular}

IQR: Interquartile range; NLR: Neutrophil-to-lymphocyte ratio; NLPR: Neutrophil-to-lymphocyte x platelet ratio; $\ddagger$ Mann-Whitney U test. 
Table 3. Postoperative laboratory data of patients

\begin{tabular}{|c|c|c|c|c|c|c|}
\hline \multirow[b]{2}{*}{ Variables } & & \multicolumn{2}{|c|}{ Group $1(n=315)$} & \multicolumn{2}{|c|}{ Group $2(\mathrm{n}=58)$} & \multirow[b]{2}{*}{$p$} \\
\hline & & Median & IQR & Median & $\mathrm{IQR}$ & \\
\hline \multirow[t]{2}{*}{ White blood cell $\left(10^{3} / \mu \mathrm{L}\right)$} & Post-cardiotomy & 11 & $4.4-26.1$ & 11.7 & $5.3-26.6$ & 0.081 \\
\hline & First day & 11.7 & $4-22.5$ & 12.1 & $8.3-22.3$ & 0.019 \\
\hline \multirow[t]{2}{*}{ Hematocrit (\%) } & Post-cardiotomy & 24 & $22.5-32$ & 24 & $21-30.4$ & 0.127 \\
\hline & First day & 27 & $24-35.6$ & 26.5 & $23.7-37$ & 0.320 \\
\hline \multirow[t]{2}{*}{ Platelet $\left(10^{3} / \mu \mathrm{L}\right)$} & Post-cardiotomy & 143.2 & $73.4-326$ & 129.5 & $70.9-230$ & $<0.001$ \\
\hline & First day & 178 & $96.9-398.7$ & 165.4 & $112.4-378.6$ & 0.109 \\
\hline \multirow[t]{2}{*}{ Neutrophil $\left(10^{3} / \mu \mathrm{L}\right)$} & Post-cardiotomy & 9.5 & $3.7-18.8$ & 11 & $4.4-19.4$ & 0.004 \\
\hline & First day & 9 & $3.2-14$ & 9.9 & $5.8-16.6$ & 0.003 \\
\hline \multirow[t]{2}{*}{ Lymphocyte $\left(10^{3} / \mu \mathrm{L}\right)$} & Post-cardiotomy & 1 & $0.1-4$ & 0.8 & $0.3-2.4$ & 0.007 \\
\hline & First day & 1.2 & $0.3-2.9$ & 1.1 & $0.3-2.4$ & 0.009 \\
\hline \multirow[t]{2}{*}{ C-reactive protein (mg/dL) } & Post-cardiotomy & - & - & - & - & - \\
\hline & First day & 86 & $6.5-213$ & 103.5 & $53.7-235$ & 0.001 \\
\hline \multirow[t]{2}{*}{ NLR } & Post-cardiotomy & 10 & $4-23.5$ & 12.4 & $4.8-38.9$ & $<0.001$ \\
\hline & First day & 6.8 & $2.5-18.3$ & 8.7 & $4.1-15$ & $<0.001$ \\
\hline \multirow[t]{2}{*}{ NLPR } & Post-cardiotomy & 7.1 & $2-21.3$ & 12 & $2.1-41.4$ & $<0.001$ \\
\hline & First day & 3.7 & $1-19.6$ & 4.4 & $1.2-21.1$ & 0.041 \\
\hline
\end{tabular}

IQR: Interquartile range; NLR: Neutrophil-to-lymphocyte ratio; NLPR: Neutrophil-to-lymphocyte x platelet ratio; $¥$ Mann-Whitney U test.

Table 4. Logistic regression analysis results

\begin{tabular}{|c|c|c|c|c|c|c|}
\hline \multirow[b]{2}{*}{ Variables } & \multicolumn{3}{|c|}{ Univariate analysis } & \multicolumn{3}{|c|}{ Multivariate analysis } \\
\hline & $p$ & $\begin{array}{c}\operatorname{Exp}(\mathrm{B}) \\
\text { Odds ratio }\end{array}$ & $\begin{array}{c}95 \% \text { CI } \\
\text { Lower upper }\end{array}$ & $p$ & $\begin{array}{c}\operatorname{Exp}(\mathrm{B}) \\
\text { Odds ratio }\end{array}$ & $\begin{array}{c}95 \% \text { CI } \\
\text { Lower upper }\end{array}$ \\
\hline Age $>65$ & 0.008 & 0.440 & $0.241-0.805$ & $\begin{array}{l}0.045^{*} \\
0.098 \dagger\end{array}$ & $\begin{array}{l}0.670^{*} \\
0.978 \dagger\end{array}$ & $\begin{array}{l}0.576-0.894^{*} \\
0.864-1.090 \dagger\end{array}$ \\
\hline Previous PCI & 0.022 & 0.502 & $0.278-0.907$ & $\begin{array}{l}0.128^{*} \\
0.905 \dagger\end{array}$ & $\begin{array}{l}1.005^{*} \\
1.164 \dagger\end{array}$ & $\begin{array}{c}0.867-1.100 * \\
0.095-14.212 \dagger\end{array}$ \\
\hline Diabetes mellitus & 0.016 & 0.475 & $0.259-0.872$ & $\begin{array}{l}0.229 * \\
0.456 \dagger\end{array}$ & $\begin{array}{l}0.894^{*} \\
1.110 \dagger\end{array}$ & $\begin{array}{l}0.756-1.009^{*} \\
0.990-1.326 \dagger\end{array}$ \\
\hline Ejection fraction (\%) & 0.148 & 1.010 & $0.786-1.110$ & - & - & - \\
\hline Body mass index & 0.216 & 0.976 & $0.877-1.090$ & - & - & - \\
\hline EuroSCORE II & $<0.001$ & 2.015 & $1.478-3.794$ & $\begin{array}{l}0.005^{*} \\
0.012 \dagger\end{array}$ & $\begin{array}{l}1.497^{*} \\
1.230 \dagger\end{array}$ & $\begin{array}{l}1.090-2.165^{*} \\
1.007-2.112 \dagger\end{array}$ \\
\hline Preoperative C-reactive protein & 0.001 & 1.062 & $1.025-1.100$ & $\begin{array}{l}0.009 * \\
0.006 \dagger\end{array}$ & $\begin{array}{l}1.061^{*} \\
1.028 \dagger\end{array}$ & $\begin{array}{l}1.015-1.110^{*} \\
1.009-1.410 \dagger\end{array}$ \\
\hline Postoperative day $1 \mathrm{C}$-reactive protein & $<0.001$ & 1.017 & $1.009-1.025$ & $\begin{array}{l}0.030^{*} \\
0.002 \dagger\end{array}$ & $\begin{array}{l}1.010^{*} \\
1.016 \dagger\end{array}$ & $\begin{array}{l}1.001-1.020 * \\
1.006-1.127 \dagger\end{array}$ \\
\hline Total perfusion time & 0.023 & 1.015 & $1.002-1.028$ & $\begin{array}{l}0.150^{*} \\
0.173 \dagger\end{array}$ & $\begin{array}{l}1.011^{*} \\
1.011 \dagger\end{array}$ & $\begin{array}{l}0.996-1.026^{*} \\
0.995-1.027 \dagger\end{array}$ \\
\hline Preoperative NLR & $<0.001$ & 1.184 & $1.108-1.265$ & $\begin{array}{c}0.001^{*} \\
<0.001 \dagger\end{array}$ & $\begin{array}{l}1.130^{*} \\
1.247 \dagger\end{array}$ & $\begin{array}{l}1.050-1.216^{*} \\
1.076-2.125 \dagger\end{array}$ \\
\hline Post-cardiotomy NLR & $<0.001$ & 1.615 & $1.312-1.988$ & $\begin{array}{c}<0.001^{*} \\
-\end{array}$ & $\begin{array}{c}1.520^{*} \\
-\end{array}$ & $\begin{array}{c}1.202-1.921 * \\
-\end{array}$ \\
\hline Post-cardiotomy platelet count & $<0.001$ & 0.984 & $0.976-0.992$ & $\begin{array}{c}0.014 * \\
-\end{array}$ & $\begin{array}{c}0.976^{*} \\
-\end{array}$ & $\begin{array}{c}0.678-0.998 * \\
-\end{array}$ \\
\hline Post-cardiotomy NLPR & $<0.001$ & 2.264 & $1.176-3.378$ & $<0.001 \dagger$ & $\begin{array}{c}- \\
1.968 \dagger\end{array}$ & $\frac{-}{1.216-3.419 \dagger}$ \\
\hline Postoperative day 1 NLR & 0.001 & 1.161 & $1.062-1.268$ & $\begin{array}{l}0.033^{*} \\
0.218 \dagger\end{array}$ & $\begin{array}{l}1.127^{*} \\
1.075 \dagger\end{array}$ & $\begin{array}{l}1.010-1.257^{*} \\
0.958-1.207 \dagger\end{array}$ \\
\hline
\end{tabular}

CI: Confidence interval; PCI: Percutaneous coronary intervention; EuroSCORE II: European System for Cardiac Operative Risk Evaluation II; NLR: Neutrophil-to-lymphocyte ratio; NLPR: Neutrophil-to-lymphocyte x platelet ratio; * Multivariate analysis Model 1, $\dagger$ Multivariate analysis Model 2. 
Table 5. Receiver operating characteristic curve analysis

\begin{tabular}{lcccccccc}
\hline \multirow{2}{*}{ Variables } & \multicolumn{3}{c}{ Univariate analysis } & & \multicolumn{3}{c}{ Multivariate analysis } \\
& Cut-off & AUC & $\begin{array}{c}95 \% \text { CI } \\
\text { Lower upper }\end{array}$ & & Sensitivity & Specificity & $p$ \\
\hline Preoperative NLR & 2.4 & 0.653 & $0.573-0.733$ & & $77.6 \%$ & $48.3 \%$ & $<0.001$ \\
Post-cardiotomy NLR & 13.3 & 0.667 & $0.586-0.748$ & & $60.8 \%$ & $80.6 \%$ & $<0.001$ \\
Post-cardiotomy NLPR & 11.2 & 0.762 & $0.658-0.836$ & & $66.9 \%$ & $88.9 \%$ & $<0.001$ \\
Postoperative day 1 NLR & 6.8 & 0.657 & & $0.590-0.724$ & & $79.3 \%$ & $50.2 \%$ & $<0.001$ \\
\hline
\end{tabular}

AUC: Area under curve; CI: Confidence interval; NLR: Neutrophil-to-lymphocyte ratio; NLPR: Neutrophil-to-lymphocyte x platelet ratio.

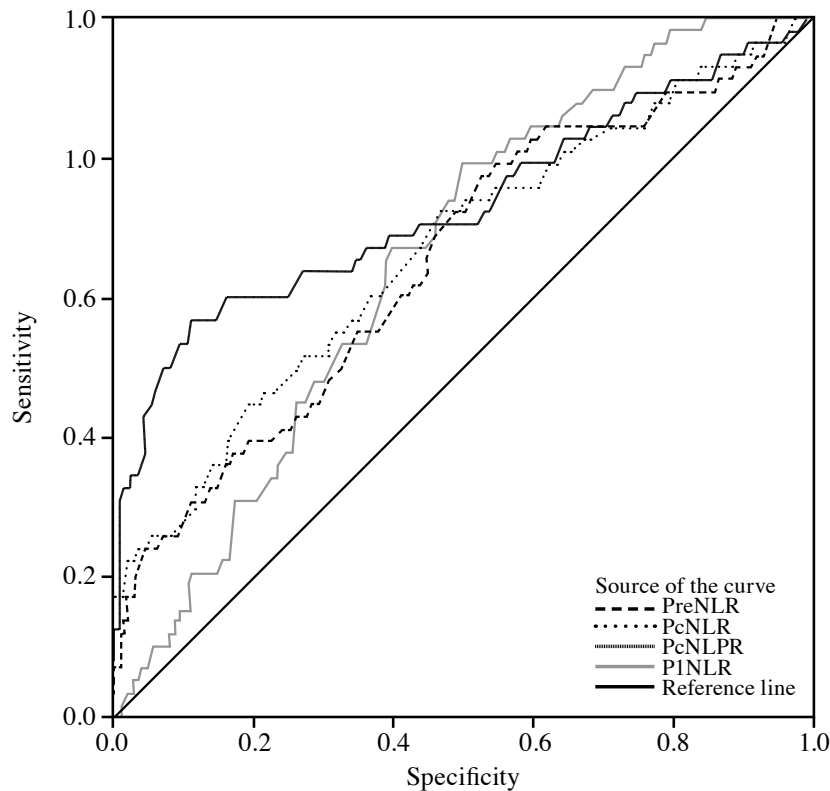

Figure 1. Receiver operating characteristic curve analysis.

The ROC analysis revealed that the cut-off values for pre-NLR, PC-NLR, PC-NLPR, and PO1-NLR were 3.24 (77.6\% sensitivity, $48.3 \%$ specificity), 13.3 (60.8\% sensitivity, $80.6 \%$ specificity), 11.2 (66.9\% sensitivity, $88.9 \%$ specificity), and 6.8 (79.3\% sensitivity, 50.2\% specificity), respectively (Table 5, Figure 1).

\section{DISCUSSION}

Routine blood parameters have been extensively studied in predicting MAEs after CABG operations. Although more sophisticated markers have been developed in recent years, routine blood parameters are easy to obtain and inexpensive, which has led clinicians to further research the subject. The NLR is the most researched marker in the diagnosis and prognosis of cardiovascular diseases. In this study, we showed that PC-NLR was more predictive of undesired results after CABG in low-risk patients, compared to pre-NLR and PO1-NLR (OR: 1.520, $\mathrm{p}<0.001$ for PC-NLR, OR: $1.130 \mathrm{p}=0.001$ for pre-NLR, OR: $1.127, \mathrm{p}=0.033$ for PO1-NLR). In the multivariate logistic regression analysis, Model 2 revealed that the PC-NLPR rate obtained by adding the platelet count to the NLR was more predictive than the NLR alone (OR: 1.968, $\mathrm{p}<0.001$ ). In the ROC curve analysis, we found that the PC-NLPR had the highest specificity in predicting postoperative MAEs (cut-off: 11.2, 66.9\% sensitivity, and $88.9 \%$ specificity).

Mortality is the most catastrophic result that can occur after CABG. Renal failure, cerebrovascular accident, serious infection, serious postoperative rhythm problems, and bleeding can lead to mortality, as well as prolonged hospital stay and increased number of working days lost. All these postoperative conditions can be defined as MAEs, and each of these events is associated with inflammation. In a study, the increased NLR was found to be associated with postoperative MAEs such as mortality, renal failure, infection, and prolonged ventilation after open heart surgery. ${ }^{[9]}$ In another study, increased NLR and low platelet values posed an increased risk of renal failure and increased all-cause mortality during the postoperative period. ${ }^{[8]}$ In contrary to these studies, we found that the relationship between PC-NLR value and platelet count obtained in the early postoperative period might be a good predictor for MAEs.

The NLR, which can be easily obtained from complete blood count parameters, has been extensively investigated in the field of cardiovascular surgery as in other fields of medicine. ${ }^{[10,11]}$ The cellular immune system is stimulated with lymphocyte activation, due to which neutrophilia occurs. Therefore, the NLR increases with the increase in the neutrophil ratio and decrease in the lymphocyte count, which has prognostic significance in various diseases. ${ }^{[12]}$ There are basically two reasons why the prognostic value of NLR is important. The first is that this value is 
less affected by possible physiological conditions, such as dehydration and exercise, compared to other inflammatory parameters. Another reason is that it is obtained by obtaining the ratio of neutrophils and lymphocytes, which are the parameters of the immune complement system. While the increase of neutrophils reveals non-specific inflammation, low lymphocyte counts indicate poor general health status and physiological stress. ${ }^{[13]}$

In their study, Gibson et al. ${ }^{[14]}$ investigated the effect of pre-NLR value on mortality after CABG. In this study, 1,938 prospectively included patients were followed for a mean of 3.6 years. As a result of univariate and multivariate analyses, the increased pre-NLR was found as an independent predictor of cardiovascular mortality (hazard ratio: 1.08 per unit, $\mathrm{p}=0.008)$. In another study, the effect of pre- and postoperative second day NLR values on the results after cardiac surgery was investigated, and the increased perioperative NLR values were found to be significantly associated with morbidity and mortality following the operation. ${ }^{[15]}$ In the retrospective cohort study of Silberman et al. ${ }^{[9]}$ including 3,027 cardiac surgeries, the effect of pre-NLR on undesired results was investigated, and increased NLR values were found to be associated with morbid results such as prolonged ventilation, mortality, and low cardiac output syndrome. In both our multivariate analyses, we determined that the pre-NLR was an independent predictor of postoperative in-hospital morbidity and mortality.

The main purpose of our study was to investigate the possible effect of the CPB system on NLR in the early period and MAEs. In CABG operations with pumps, the blood comes into contact with the outer surfaces and, thus, inflammatory changes occur. The kallikrein is activated, which eventually activates neutrophils, leading to chemotactic stimulation and organ damage. Activated cytokines and free oxygen radicals released from the neutrophil granules contribute to this damage. ${ }^{[16]} \mathrm{T}$ and $\mathrm{B}$ cells, which are the components of the adaptive immune system, can be also activated during cardiac surgery and in the early period. ${ }^{[17]}$ The postoperative results may be affected due to all aforementioned reasons. ${ }^{[18]}$

Although there are numerous studies in the literature investigating the NLR obtained on Day 1, 2, and 7 after open heart surgeries, the PC-NLR research has been very limited. ${ }^{[19]}$ This may be due the fact that prospective studies remain restricted and routine hemogram assessment is not performed upon entry to the ICU in most clinics. Kim et al. ${ }^{[20]}$ retrospectively investigated the effects of pre-NLR, PC-NLR, and NLR calculated on the first postoperative day on mortality and renal failure in 590 patients who underwent cardiac surgery to identify whether PC-NLR and NLR obtained on the first day after the operation were associated with early-stage renal failure. In addition, when used as a continuous variable, the PC-NLR value was determined as an independent predictor of oneyear mortality due to all causes (OR: 1.02, p=0.006). Above 10, this variable was found to be quite highly predictive of one-year mortality (OR: $8.40,95 \% \mathrm{CI}$ : 2.50-28.17, $\mathrm{p}<0.001)$. In our study, we found that, compared to other variables, the PC-NLR was more predictive of postoperative MAEs in both multivariate analyses.

Platelets play a significant role in important tasks in the human body, such as hemostasis, tissue regeneration, thromboxane synthesis, and synthesis of adhesion molecules. ${ }^{[21]}$ Cardiac surgery under CPB is known to lead to platelet activation, which can cause complications such as stroke and myocardial infarction in the postoperative period. ${ }^{[22]}$ Its occurrence has been also associated with prolonged intensive care hospitalization, increased mortality, and renal insufficiency in these patients..$^{[23]}$

Numerous studies have been conducted investigating the effectiveness of increased platelet counts in the diagnosis and prognosis of cardiovascular diseases. ${ }^{[19]}$ However, our study is different in terms of demonstrating the effects of postcardiotomy low platelets on postoperative MAEs. Following cardiac surgery, platelets are effective through possible pathological consequences of bleeding mechanisms rather than thrombosis. As a result of the cellular and humoral system activation that occurs during and after $\mathrm{CPB}$, a complex process involving platelets, vascular endothelium, fibrinogen, and neutrophils occurs, thereby, inducing a pathological process which progresses from bleeding risk to microthrombi. ${ }^{[24]}$ Accordingly, in a study including 4,217 CABG patients by Kertai et al., ${ }^{[4]}$ decreased postoperative platelet counts were associated with early-stage renal failure and mortality.

In the light of all these data, a new ratio was put forward by Koo et al. ${ }^{[8]}$ in 2018 in predicting potential poor outcomes following cardiac surgery operations. At the beginning of the study, the authors assumed that the NLPR obtained by adding the platelet count to the denominator of NLR could be a more valuable marker in predicting undesired outcomes. In this study, 1,099 adult cardiac surgeries were evaluated, and the NLR and NLPR values were 
calculated from complete blood count obtained in four different timepoints (preoperative, post-cardiotomy, and postoperative Days 1 and 2). In the multivariate analysis, the highest measured NLPR was found to be an independent predictor of early-stage renal failure and mortality for all five-year causes. In our study, we showed that NLPR was more predictive than NLR alone in predicting early MAEs after CABG. Also, in contrast to this study, we added the values related to the pre-NLR and NLPR to our data tables to achieve more reliable results.

In the current study, for pre-NLR, PC-NLR, PO1-NLR, and PC-NLPR, the ROC curves showed relatively low AUCs. Of note, it is worth to remind that none of these tests are diagnostic, but they are helpful in showing an increased level of inflammation which goes along with MAEs. They are easily accessible, inexpensive complete blood count parameters may be valuable in predicting MAEs. In addition, factors such as diabetes mellitus and age were also found to be higher in Group 2. These variables may be associated with increased MAEs ratios, as well as increased NLR values. Based on our study results, we believe that these blood parameters can be used as a supportive tool in addition to known risk factors.

Nonetheless, there are some limitations to this study. It has a retrospective design which may have led to study biases. In addition, the mean age and the rate of diabetes mellitus were higher in Group 2 than Group 1 which made Group 2 patients more susceptible to postoperative MAEs. Also, blood transfusion was unable to be evaluated in the study; however, the amount of blood transfusion is closely associated with prolonged intubation time and length of ICU and hospital stay, since the increased blood product use results in increased hemolysis, leading to microvascular complications by increasing the free iron content in the blood. ${ }^{[25]}$ Finally, our study is a single center study with a relatively small sample size to make powerful predictions. The main strength of this study, on the other hand, is that the rate of NLPR was, for the first time, found to be associated with MAEs occurring after CABG. We believe that our study would inspire further large-scale, multi-center studies using subgroup analyses for poor postoperative outcomes.

In conclusion, high neutrophil-to-lymphocyte ratios have been accepted as a risk factor for cardiovascular disease. Our study results show that post-cardiotomy neutrophil-to-lymphocyte ratio and neutrophil-to-lymphocyte $\mathrm{x}$ platelet ratio, which are easily accessible, inexpensive complete blood count parameters, may be more valuable in predicting postoperative major adverse events. However, further multi-center studies in larger patient series are needed to demonstrate the predictive value of post-cardiotomy neutrophil-to-lymphocyte ratio and neutrophil-to-lymphocyte $\mathrm{x}$ platelet ratio.

\section{Declaration of conflicting interests}

The authors declared no conflicts of interest with respect to the authorship and/or publication of this article.

\section{Funding}

The authors received no financial support for the research and/or authorship of this article.

\section{REFERENCES}

1. Gomes WJ, Moreira RS, Zilli AC, Bettiati LC Jr, Figueira FAMDS, D' Azevedo SSP, et al. The Brazilian Registry of Adult Patient Undergoing Cardiovascular Surgery, the BYPASS Project: Results of the First 1,722 Patients. Braz J Cardiovasc Surg 2017;32:71-6.

2. Taylor KM. SIRS--the systemic inflammatory response syndrome after cardiac operations. Ann Thorac Surg 1996;61:1607-8.

3. Sargın M, Taşdemir Mete M, Bayer Erdoğan S, Kuplay H, Baştopçu M, Bayraktar F, et al. Neutrophil-to-lymphocyte ratio for early renal failure under extracorporeal membrane oxygenation support for postcardiotomy shock. Turk Gogus Kalp Dama 2019;27:314-9.

4. Kertai MD, Zhou S, Karhausen JA, Cooter M, Jooste E, Li $\mathrm{YJ}$, et al. Platelet counts, acute kidney injury, and mortality after coronary artery bypass grafting surgery. Anesthesiology 2016;124:339-52.

5. Argiriadou H, Antonitsis P, Gkiouliava A, Papapostolou E, Deliopoulos A, Anastasiadis K. Minimal invasive extracorporeal circulation preserves platelet function after cardiac surgery: a prospective observational study. Perfusion 2020;35:138-44.

6. Mazzeffi M, Lund L, Wallace K, Herrera AV, Tanaka K, Odonkor $\mathrm{P}$, et al. Effect of cardiopulmonary bypass on platelet mitochondrial respiration and correlation with aggregation and bleeding: a pilot study. Perfusion 2016;31:508-15.

7. Gameiro J, Fonseca JA, Dias JM, Milho J, Rosa R, Jorge S, et al. Neutrophil, lymphocyte and platelet ratio as a predictor of postoperative acute kidney injury in major abdominal surgery. BMC Nephrol 2018;19:320.

8. Koo CH, Eun Jung D, Park YS, Bae J, Cho YJ, Kim WH, et al. Neutrophil, lymphocyte, and platelet counts and acute kidney injury after cardiovascular surgery. J Cardiothorac Vasc Anesth 2018;32:212-22.

9. Silberman S, Abu-Yunis U, Tauber R, Shavit L, Grenader T, Fink D, et al. Neutrophil-lymphocyte ratio: Prognostic impact in heart surgery. Early outcomes and late survival. Ann Thorac Surg 2018;105:581-6.

10. Yost G, Bhat G, Pappas P, Tatooles A. The neutrophil to lymphocyte ratio in patients supported with extracorporeal membrane oxygenation. Perfusion 2018;33:562-7. 
11. Kalkan ME, Kalkan AK, Gündeş A, Yanartaş M, Oztürk S, Gurbuz AS, et al. Neutrophil to lymphocyte ratio: a novel marker for predicting hospital mortality of patients with acute type A aortic dissection. Perfusion 2017;32:321-7.

12. Gurbuz O, Kumtepe G, Ozkan H, Karal IH, Velioglu Y, Ercan A, et al. Predictive Value of Neutrophil-Lymphocyte Ratio for Long-Term Cardiovascular Event Following Coronary Artery Bypass Grafting. Braz J Cardiovasc Surg 2020;35:274-84.

13. Azab B, Zaher M, Weiserbs KF, Torbey E, Lacossiere K, Gaddam S, et al. Usefulness of neutrophil to lymphocyte ratio in predicting short- and long-term mortality after non-ST-elevation myocardial infarction. Am J Cardiol 2010;106:470-6.

14. Gibson PH, Croal BL, Cuthbertson BH, Small GR, Ifezulike AI, Gibson G, et al. Preoperative neutrophil-lymphocyte ratio and outcome from coronary artery bypass grafting. Am Heart J 2007;154:995-1002.

15. Giakoumidakis K, Fotos NV, Patelarou A, Theologou S, Argiriou M, Chatziefstratiou AA, et al. Perioperative neutrophil to lymphocyte ratio as a predictor of poor cardiac surgery patient outcomes. Pragmat Obs Res 2017;8:9-14.

16. Vohra HA, Whistance R, Modi A, Ohri SK. The inflammatory response to miniaturised extracorporeal circulation: a review of the literature. Mediators Inflamm 2009;2009:707042.

17. Markewitz A, Lante W, Franke A, Marohl K, Kuhlmann WD, Weinhold C. Alterations of cell-mediated immunity following cardiac operations: clinical implications and open questions. Shock 2001;16 Suppl 1:10-5.

18. Pearson TA, Mensah GA, Alexander RW, Anderson JL, Cannon RO 3rd, Criqui M, et al. Markers of inflammation and cardiovascular disease: application to clinical and public health practice: A statement for healthcare professionals from the Centers for Disease Control and Prevention and the American Heart Association. Circulation 2003;107:499-511.

19. Parlar H, Şaşkın H. Are pre and postoperative platelet to lymphocyte ratio and neutrophil to lymphocyte ratio associated with early postoperative AKI following CABG? Braz J Cardiovasc Surg 2018;33:233-41.

20. Kim WH, Park JY, Ok SH, Shin IW, Sohn JT. Association between the neutrophil/lymphocyte ratio and acute kidney injury after cardiovascular surgery: a retrospective observational study. Medicine (Baltimore) 2015;94:e1867.

21. Karagoz I, Aktas G, Yoldas H, Yildiz I, Ogun MN, Bilgi $\mathrm{M}$, et al. Association between hemogram parameters and survival of critically Ill patients. J Intensive Care Med 2019;34:511-3.

22. Ranucci M. Hemostatic and thrombotic issues in cardiac surgery. Semin Thromb Hemost 2015;41:84-90.

23. Williamson DR, Albert M, Heels-Ansdell D, Arnold DM, Lauzier F, Zarychanski R, et al. Thrombocytopenia in critically ill patients receiving thromboprophylaxis: frequency, risk factors, and outcomes. Chest 2013;144:1207-15.

24. Zhou S, Fang Z, Xiong H, Hu S, Xu B, Chen L, et al. Effect of one-stop hybrid coronary revascularization on postoperative renal function and bleeding: a comparison study with offpump coronary artery bypass grafting surgery. J Thorac Cardiovasc Surg 2014;147:1511-6.e1.

25. Koçyiğit M, Ulugöl H, Kıran Sİ, Alhan C, Toraman F. Did blood transfusion increase mortality in patients with diabetes undergoing isolated coronary artery bypass graft surgery? A propensity score-matched analysis of 816 patients. Turk Gogus Kalp Dama 2020;28:586-92. 